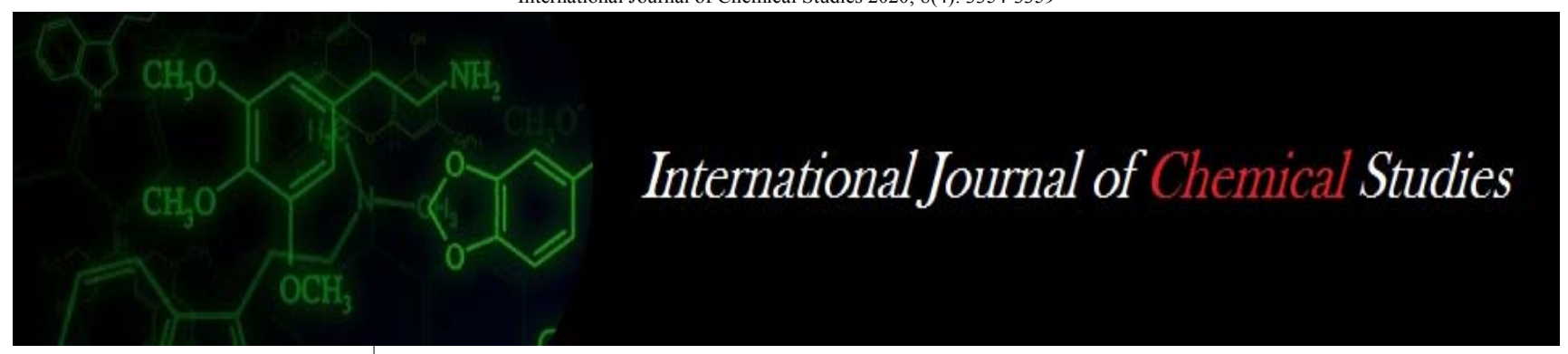

P-ISSN: 2349-8528

E-ISSN: 2321-4902

www.chemijournal.com

IJCS 2020; 8(4): 3354-3359

(C) 2020 IJCS

Received: 16-05-2020

Accepted: 22-06-2020

MS Devi

Department of Genetics and Plant Breeding, SV. Agricultural college, ANGRAU, Tirupati, Andhra Pradesh, India

DM Reddy

Regional Agricultural Research Station, ANGRAU, Tirupati,

Andhra Pradesh, India

\section{KHP Reddy}

Department of Genetics and Plant Breeding, SV. Agricultural college, ANGRAU, Tirupati, Andhra Pradesh, India

\section{Reddy}

Department of Genetics and Plant Breeding, SV. Agricultural college, ANGRAU, Tirupati,

Andhra Pradesh, India

\section{VLN Reddy}

Department of Genetics and

Plant Breeding, SV. Agricultural college, ANGRAU, Tirupati,

Andhra Pradesh, India

P Sudhakar

Administrative office, ANGRAU, Lam, Guntur, Andhra Pradesh, India
Corresponding Author: MS Devi

Department of Genetics and Plant Breeding, SV. Agricultural college, ANGRAU, Tirupati, Andhra Pradesh, India

\section{Comparative effectiveness and efficiency of gamma rays, ethyl methane sulfonate and maleic hydrazide in induction of chlorophyll mutations in black gram (Vigna mungo (L.) Hepper)}

\author{
MS Devi, DM Reddy, KHP Reddy, DL Reddy, VLN Reddy and P \\ Sudhakar
}

DOI: $\underline{\text { https://doi.org/10.22271/chemi.2020.v8.i4ap.10171 }}$

\begin{abstract}
The present investigation was taken up to study the effectiveness and efficiency of gamma rays, ethyl methane sulfonate and maleic hydrazide in induction of chlorophyll mutations in two blackgram varieties viz., LBG 752 and TBG 104. The seeds were treated with different doses/concentrations of gamma rays (200 Gy, $300 \mathrm{~Gy}, 400 \mathrm{~Gy}, 500 \mathrm{~Gy}$ and $600 \mathrm{~Gy})$, EMS (Ethyl methane sulfonate) $(0.2 \%, 0.3 \%$, 0.4\%, $0.5 \%$ and $0.6 \%$ ) and $\mathrm{MH}$ (Maleic Hydrazide) $(0.01 \%, 0.02 \%$ and $0.03 \%)$. A wide spectrum of chlorophyll mutations viz., albina, xantha and chlorina was observed in $\mathrm{M}_{2}$ generation and chlorina was the most frequent chlorophyll mutant in all the mutagen treated populations of both the varieties. There was a dose dependent increase in the frequency of chlorophyll mutations. This study showed that the effectiveness and efficiency of chlorophyll mutations declined considerably with the increase in dose of the mutagens. MH treatments were more effective followed by EMS and gamma rays treatments in both the varieties. With respect to efficiency, the gamma rays were more efficient followed by EMS and MH treatments in both the varieties for inducing chlorophyll mutations on the basis of injury, lethality and sterility except based on lethality in TBG 104, where MH treatments showed highest value followed by gamma rays and EMS treatments.
\end{abstract}

Keywords: blackgram, effectiveness, efficiency, gamma rays, EMS, MH, frequency and spectrum

\section{Introduction}

Blackgram is an important pulse crop of Indian agriculture. Among pulses, it ranks fourth in production and acreage. However, keeping in view the future demands for maintaining nutritional security, there is an immediate need to increase the production and productivity of blackgram. As genetic variability is essential for any crop improvement programme, induced mutations provide an important source for variability. In order to exploit induced mutagenesis for crop improvement, the basic studies on effectiveness and efficiency of a mutagen in a crop is necessary to recover high frequency of desirable mutations (Kousar and Suresh, 2010) ${ }^{[12]}$. Mutagenic effectiveness is a measure of the frequency of mutations induced with application of unit dose of a mutagen, whereas mutagenic efficiency indicates the proportion of mutations in the $\mathrm{M}_{2}$ generation in relation to the biological damage such as gross chromosomal aberrations, lethality, sterility caused in $\mathrm{M}_{1}$ (Konzak et al., 1965) ${ }^{[11]}$.

Though chlorophyll mutations are considered to be less important from crop improvement point of view, still they act as indicators of effectiveness of mutagenic treatments in inducing other mutations observed in $\mathrm{M}_{2}$ generation. Chlorophyll mutations are most dependable indices for the evaluation of genetic effects of mutagenic treatments, since they are more conspicuous and are easily detectable. They have been extensively used to find out sensitivity of crop plants to mutagens and to elucidate effectiveness and efficiency of a mutagen (Gustafsson, 1940) ${ }^{[9]}$.

Therefore, the present investigation was undertaken to compare mutagenic effectiveness and efficiency of gamma rays, EMS and MH based on the frequency of chlorophyll mutations in $\mathrm{M}_{2}$ generations of LBG 752 and TBG 104 blackgram varieties. 


\section{Material and methods}

In the present investigation, two promising blackgram varieties of Andhra Pradesh viz., LBG 752 and TBG 104 were used. Well filled, undamaged and uniform sized seeds were handpicked from the seed lot and equilibrated to the moisture content of 12 per cent. For each dose/concentration 750 seeds were treated in each variety. For gamma irradiation studies, the seeds were irradiated with different doses of gamma rays viz., $200 \mathrm{~Gy}, 300 \mathrm{~Gy}, 400 \mathrm{~Gy}, 500 \mathrm{~Gy}$ and $600 \mathrm{~Gy}$ at BARC, Trombay. Similarly, for chemical mutagen treatment, the seeds were treated with five different concentrations viz., $0.2 \%, 0.3 \%, 0.4 \%, 0.5 \%$ and $0.6 \%$ of EMS and three different concentrations of $\mathrm{MH}$ viz., $0.01 \%, 0.02 \%$ and $0.03 \%$ in the Department of Genetics and Plant Breeding, Sri Venkateswara Agricultural College, Tirupati during rabi, 2017. The seeds of both varieties were soaked for six hours in distilled water before chemical mutagen treatment. The presoaked seeds after removal from the water were placed between folds of blotting paper to remove the water adhered on the surface. Then the seeds were immersed for six hours in the requisite concentration of mutagen with intermittent shaking. To ensure uniform absorption of the mutagen, the volume of the mutagen solution was maintained at a proportion of ten times to that of seed volume. The whole treatment was carried out at room temperature of $23 \pm 1^{0} \mathrm{C}$. Immediately after the completion of treatment duration, treated seeds were thoroughly washed in running water for half-an-hour. Treated seeds of gamma rays, EMS and MH along with equal number of controls (untreated) were sown immediately in the field in a randomized block design with three replications. Data on biological abnormalities such as injury, letality and sterility were recorded in $\mathrm{M}_{1}$ generation. Normal looking plants of $M_{1}$ generation with sufficient seed in different treatments were selected to raise $\mathrm{M}_{2}$ generation in compact family block design with two replications. Observations on chlorophyll mutations were recorded from $5^{\text {th }}$ to $15^{\text {th }}$ day of sowing and were classified in accordance with the system of Gustafsson (1940) ${ }^{[9]}$. The frequency of chlorophyll mutations was calculated on $\mathrm{M}_{2}$ plant population basis as follows.

Mutation frequency $(\%)=\frac{\text { Number of mutants }}{\text { Total } \mathrm{M}_{2} \text { plants }} \times 100$

The effectiveness and efficiency of the mutagens were worked out by using the formula as suggested by Konzak et al. $(1965)^{[11]}$.

Mutagenic effectiveness $(\%)=\frac{\mathrm{M}_{\mathrm{p}} \times 100}{\text { Gy or } \mathrm{T} \times \mathrm{C}}$

Where,

$\mathrm{M}_{\mathrm{p}}$ - Chlorophyll mutation frequency on $\mathrm{M}_{2}$ plant basis

Gy - Dose of gamma radiation

$\mathrm{T}$ - Duration of mutagenic treatment

C - Concentration of mutagen

Mutagenic efficiency $(\%)=\mathrm{Mp} \times 100 / \mathrm{L}$

$\mathrm{Mp} \times 100 / \mathrm{I}$

$\mathrm{Mp} \times 100 / \mathrm{S}$

Where,

Mp - Chlorophyll or viable mutation frequency on $\mathrm{M}_{2}$ plant basis
L - Percentage of lethality i.e., percentage of reduction in survival of seedlings on $30^{\text {th }}$ day after sowing

I - Percentage of injury i.e., percentage of height reduction of seedlings on $30^{\text {th }}$ day after sowing

$\mathrm{S}$ - Percentage of sterility i.e., percentage of reduction in pollen fertility

\section{Results and discussion}

\section{Frequency and spectrum of chlorophyll mutations}

Chlorophyll mutations provide one of the most dependable indices for the evaluation of genetic effects of mutagenic treatments and have also been reported earlier in blackgram (Souframanien et al., 2016; Dhasarathan et al., 2017 and Tamilzharasi et al., 2019) ${ }^{[16,5,18]}$. Gaul (1964) ${ }^{[6]}$ reported that chlorophyll mutations are employed as markers for the evaluation of gene action of mutagenic factors in inducing mutation. Mutation in chlorophyll genes may induce chlorophyll mutation. The origin of chlorophyll deficiencies is mainly due to mutation in gene, which are responsible for synthesis of photosynthetic pigments. In the present investigation, the frequency and spectrum of chlorophyll mutants were observed in $\mathrm{M}_{2}$ generation and are presented in Tables 1 and 2 for LBG 752 and TBG 104, respectively. In gamma rays treatments, the frequency of chlorophyll mutants in $\mathrm{M}_{2}$ population of LBG 752 ranged between 1.846 (200 Gy) to 3.476 per cent (600 Gy) and in TBG 104, it was between 1.648 (200 Gy) and 2.887 per cent (600 Gy). In EMS treatments, the frequency of chlorophyll mutants ranged from $1.060(0.2 \%)$ to 2.106 per cent $(0.6 \%)$ in LBG 752 and from $2.515(0.2 \%)$ to 4.195 per cent $(0.6 \%)$ in TBG 104 mutated populations. In $\mathrm{MH}$ treatments, the chlorophyll mutant frequency varied from $0.889(0.01 \%)$ to 1.147 per cent $(0.03 \%)$ in LBG 752 mutated population and $3.506(0.01 \%)$ to 7.082 per cent $(0.03 \%)$ in TBG 104 mutated population. There was a dose dependent increase in the frequency of chlorophyll mutation in gamma rays, EMS and $\mathrm{MH}$ treated $\mathrm{M}_{2}$ populations in both the varieties. Similar trend was also observed by Souframanien et al. (2016) [16], Goyal et al. (2019) ${ }^{[8]}$ and Tamilzharasi et al. (2019) ${ }^{[18]}$. The increased chlorophyll mutation frequency at higher doses may be attributed to the chromosomal aberrations or saturation in the mutational events which may result in the elimination of mutant cells during growth (Brock, 1965) ${ }^{[3]}$.

The two blackgram varieties viz., LBG 752 and TBG 104 responded differently to different mutagens with respect to frequency of chlorophyll mutations. In LBG 752, the average frequency of chlorophyll mutations was highest in gamma rays treated population ( 2.413 per cent) followed by EMS (1.609 per cent) and $\mathrm{MH}$ (1.036 per cent) treated populations. Whereas, in TBG 104, the frequency of chlorophyll mutations was highest in $\mathrm{MH}$ treated population (5.238 per cent) followed by EMS (3.221 per cent) and gamma rays (2.365 per cent) treated populations. Gamma rays treatments showed highest average chlorophyll mutation frequency in LBG 752 , while $\mathrm{MH}$ treatments showed the highest average mutation frequency in TBG 104.

In this study, a wide spectrum of chlorophyll mutations were observed in mutagen treated populations of LBG 752 and TBG 104 in $\mathrm{M}_{2}$ generation, which included albina, xantha and chlorina types (Plate 1). No chlorophyll mutations were observed in untreated (control) population. Among different types of chlorophyll mutants, chlorina was the most frequent in gamma rays, EMS and MH treated population of LBG 752 and TBG 104 followed by xantha and albina. The higher proportion of chlorina was in agreement with findings of 
Dhasarathan et al. (2017) ${ }^{[5]}$ and Tamilzharasi et al. (2019) ${ }^{[18]}$ in blackgram. The albina type of chlorophyll mutants were not found in $\mathrm{MH}$ treated population of both the varieties.

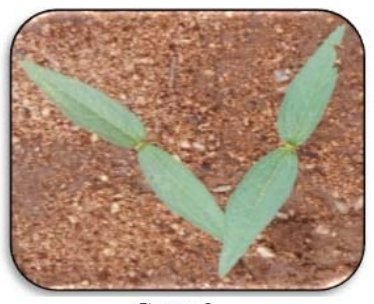

Control

Xantha

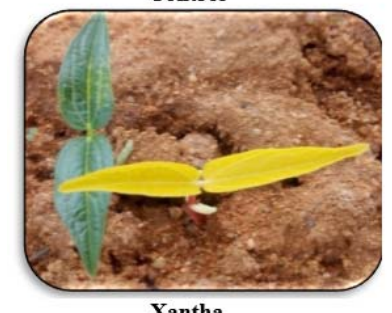

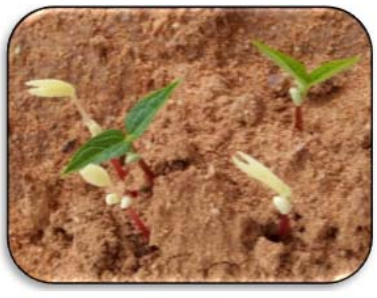

Albina

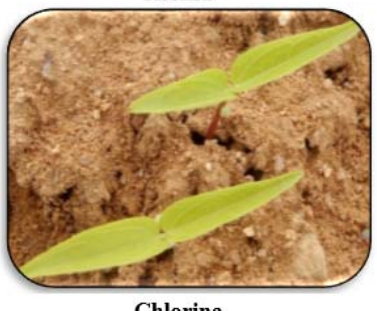

Chlorina
Plate 1: Chlorophyll mutants observed in $\mathrm{M}_{2}$ generation

\section{Mutagenic effectiveness and efficiency based on chlorophyll mutations}

The Mutagenic effectiveness and efficiency based on chlorophyll mutations in LBG 752 and TBG 104 are presented in Tables 3 and 4, respectively. Konzak et al. $(1965)^{[11]}$ had presented a detailed account of the mutagenic effectiveness and efficiency. The term effectiveness is a measure of gene mutation in relation to dose and efficiency is an estimate of biological effects induced, such as lethality, sterility and injury. To obtain high efficiency, the mutagenic effect must greatly surpass the damage in the cells and chromosomal aberrations as proposed by Gaul et al. (1972) ${ }^{[7]}$. The effectiveness of gamma rays in inducing chlorophyll mutations ranged from 0.005 to 0.009 per cent with the highest effectiveness at 200 Gy of gamma rays in LBG 752, whereas in TBG 104 it varied from 0.005 to 0.008 per cent with highest effectiveness at 200 Gy of gmma rays. The effectiveness of EMS in inducing chlorophyll mutations ranged from 0.585 to 0.883 per cent in LBG 752 and in TBG 104 , it ranged from 1.165 to 2.096 per cent with the highest mutagenic effectiveness in both the varieties at $0.2 \%$ of EMS. With respect to $\mathrm{MH}$ treatments in LBG 752, it ranged from 6.374 to 14.822 per cent and in TBG 104, it varied from 39.345 to 58.431 per cent and the highest effectiveness was noticed at $0.01 \%$ of $\mathrm{MH}$ in both the varieties.

In LBG 752, the highest average mutagenic effectiveness of chlorophyll mutants was recorded in $\mathrm{MH}$ treatments (10.040 per cent) followed by EMS treatments ( 0.704 per cent) and gamma rays treatments $(0.007$ per cent $)$. Similarly, in TBG 104, the highest average mutagenic effectiveness of chlorophyll mutants was recorded in MH treatments (46.837 per cent) followed by EMS treatments (1.453 per cent) and gamma rays treatments ( 0.006 per cent). In the present study, the effectiveness of chlorophyll mutants showed a trend, which was inversely proportional to the increasing dose of mutagens. Among all mutagenic treatments studied, gamma rays at $200 \mathrm{~Gy}$ of gamma rays, $0.2 \%$ of EMS and $0.01 \%$ of $\mathrm{MH}$ were the most effective treatments in both the varieties. Among the mutagens, $\mathrm{MH}$ treatments were more effective followed by EMS and gamma rays treatments in both the varieties. Such a dose dependent findings agreed to the earlier response of Bhosale et al. (2013) ${ }^{[1,2]}$, Bhosale and Hallale
(2013) $)^{[1,2]}$ and Dhasarathan et al. (2017) ${ }^{[5]}$. In contrast to this, Ramchander et al. (2018) [13] reported high mutagenic effectiveness at higher doses and low mutagenic effectiveness at lower doses. Khan and Hashim (1979) ${ }^{[10]}$ and Reddi and Sunnetha (1992) ${ }^{[14]}$ reported that the effectiveness did not necessarily increase linearly with the increasing doses, rather every dose has its own effectiveness, independent of the other lower and higher doses.

The mutagenic efficiency varied depending on the criteria selected. The efficiency estimated on the basis of injury was generally higher compared with lethality and sterility. This observation was consistent with the findings of Souframanien et al. (2016) ${ }^{[16]}$. The lethality, injury and sterility were the highest when higher doses of mutagenic treatments were used. In gamma rays treatments, the highest efficiency was observed at 200 Gy of gamma rays on the basis of lethality $(0.119$ per cent and 0.167 per cent $)$, injury $(0.265$ per cent and 0.183 per cent) and sterility ( 0.300 per cent and 0.496 per cent) in LBG 752 and TBG 104. In LBG 752, the average mutagenic efficiency of gamma rays in inducing chlorophyll mutations based on lethality, injury and sterility was 0.061 per cent, 0.204 per cent and 0.120 per cent, respectively. In TBG 104 , the average mutagenic efficiency of gamma rays in inducing chlorophyll mutations based on lethality, injury and sterility was 0.089 per cent, 0.142 per cent and 0.275 per cent, respectively.

In EMS treatments, the highest efficiency was observed at $0.2 \%$ of EMS on the basis of lethality ( 0.038 per cent and 0.423 per cent), injury ( 0.083 per cent 0.664 per cent) and sterility ( 0.032 per cent and 0.932 per cent) in LBG 752 and TBG 104. In LBG 752, the average mutagenic efficiency of EMS in inducing viable mutations based on lethality, injury and sterility was 0.031 per cent, 0.062 per cent and 0.031 per cent, respectively. In TBG 104, the average mutagenic efficiency of EMS in inducing chlorophyll mutations based on lethality, injury and sterility was 0.149 per cent, 0.218 per cent and 0.348 per cent, respectively.

With respect to $\mathrm{MH}$ treatments, the highest efficiency was observed at $0.02 \%$ and $0.03 \%$ of $\mathrm{MH}$ on the basis of lethality ( 0.013 per cent), $0.02 \%$ of $\mathrm{MH}$ on the basis of injury $(0.033$ per cent) and $0.01 \%$ of $\mathrm{MH}$ on the basis of sterility $(0.070$ per cent) in LBG 752 and in TBG 104, the highest efficiency was observed at $0.03 \%$ of $\mathrm{MH}$ on the basis of lethality $(0.081$ per cent), $0.03 \%$ of $\mathrm{MH}$ on the basis of injury ( 0.149 per cent) and $0.01 \%$ of $\mathrm{MH}$ on the basis of sterility ( 0.280 per cent). In LBG 752, the average mutagenic efficiency of MH treatments in inducing chlorophyll mutations based on lethality, injury and sterility was 0.012 per cent, 0.030 per cent and 0.039 per cent, respectively. In TBG 104, the average mutagenic efficiency of $\mathrm{MH}$ treatments in inducing chlorophyll mutations based on lethality, injury and sterility was 0.603 per cent, 0.137 per cent and 0.164 per cent, respectively.

Based on lethality and injury, the average mutagenic efficiency in inducing chlorophyll mutations was highest in gamma rays followed by EMS and MH treatments, whereas based on sterility, it was highest in gamma rays followed by MH and EMS treatments. The efficiency of gamma rays, EMS and $\mathrm{MH}$ treatments declined considerably with the increase in dose of the mutagens with few exceptions. The decrease in efficiency at higher dose might be attributed to the failure in recovery of viable mutations proportion to the dose of the mutagen. This result was consistent with findings of Usharani and Kumar (2015) ${ }^{[19]}$, Souframanien et al. (2016) ${ }^{[16]}$ and Dhasarathan et al. (2017) ${ }^{[5]}$ in blackgram. The reason for the greater efficiency at lower concentrations of mutagen 
would be due to the fact that the lethality, injury and sterility increased with the mutagen level at faster rate. So, the lower concentration caused relatively less damage which enabled the organisms to manifest the induced mutations more frequently (Shadakshari et al., 2001). The high mutagenic efficiency, mostly at lower and intermediate doses of viable mutants than higher doses were previously reported by Surendar et al. (2014) in blackgram. Bhosale and Hallale (2013) ${ }^{[1,2]}$ reported gradual increase in mutagenic efficiency with increasing concentration or doses of the mutagens. Based on the present results, gamma rays were more efficient followed by EMS and MH treatments in both the varieties for inducing chlorophyll mutations on the basis of injury, lethality and sterility except based on lethality in TBG 104, where $\mathrm{MH}$ treatments showed higher value followed by gamma rays and EMS treatments. Deepalakshmi and Kumar (2003) also reported high efficiency of gamma rays in inducing chlorophyll mutations in blackgram. However, Bhosale and Hallale (2013) ${ }^{[1,2]}$ and Usharani and Kumar (2015) ${ }^{[19]}$ reported EMS as the most efficient mutagen in blackgram.

Table 1: Frequency and spectrum of chlorophyll mutants in $\mathrm{M}_{2}$ generation of LBG 752

\begin{tabular}{|c|c|c|c|c|c|c|c|c|c|c|}
\hline \multirow{2}{*}{\multicolumn{2}{|c|}{ Treatments }} & \multirow{2}{*}{$\begin{array}{l}\text { Total number } \\
\text { of seedlings } \\
\text { examined }\end{array}$} & \multicolumn{3}{|c|}{ Types of chlorophyll mutants } & \multirow{2}{*}{$\begin{array}{l}\text { Total number of } \\
\text { chlorophyll } \\
\text { mutants }\end{array}$} & \multicolumn{3}{|c|}{$\begin{array}{c}\text { Relative percentage (Frequency) } \\
\text { of chlorophyll mutants }\end{array}$} & \multirow{2}{*}{$\begin{array}{c}\text { Chlorophyll } \\
\text { mutation } \\
\text { frequency (\%) }\end{array}$} \\
\hline & & & Albina & Xantha & Chlorina & & Albina & Xantha & Chlorina & \\
\hline \multicolumn{2}{|c|}{ Control } & 2200 & - & - & - & - & - & - & - & - \\
\hline \multirow{5}{*}{$\begin{array}{c}\text { Gamma } \\
\text { rays }\end{array}$} & $200 \mathrm{~Gy}$ & 1029 & 1 & 9 & 9 & 19 & 0.097 & 0.875 & 0.875 & 1.846 \\
\hline & $300 \mathrm{~Gy}$ & 455 & 0 & 2 & 8 & 10 & 0.000 & 0.440 & 1.758 & 2.198 \\
\hline & $400 \mathrm{~Gy}$ & 1072 & 0 & 9 & 15 & 24 & 0.000 & 0.840 & 1.399 & 2.239 \\
\hline & $500 \mathrm{~Gy}$ & 1215 & 0 & 2 & 26 & 28 & 0.000 & 0.165 & 2.140 & 2.305 \\
\hline & $600 \mathrm{~Gy}$ & 863 & 4 & 6 & 20 & 30 & 0.463 & 0.695 & 2.317 & 3.476 \\
\hline \multicolumn{2}{|c|}{ Mean } & - & - & - & - & - & - & - & - & 2.413 \\
\hline \multirow{5}{*}{ EMS } & $0.2 \%$ & 1038 & 0 & 3 & 8 & 11 & 0.000 & 0.289 & 0.771 & 1.060 \\
\hline & $0.3 \%$ & 915 & 0 & 2 & 10 & 12 & 0.000 & 0.219 & 1.093 & 1.311 \\
\hline & $0.4 \%$ & 1488 & 1 & 6 & 17 & 24 & 0.067 & 0.403 & 1.142 & 1.613 \\
\hline & $0.5 \%$ & 1023 & 0 & 6 & 14 & 20 & 0.000 & 0.587 & 1.369 & 1.955 \\
\hline & $0.6 \%$ & 1187 & 2 & 10 & 13 & 25 & 0.168 & 0.842 & 1.095 & 2.106 \\
\hline \multicolumn{2}{|c|}{ Mean } & - & - & - & - & - & - & - & - & 1.609 \\
\hline \multirow{3}{*}{$\mathrm{MH}$} & $0.01 \%$ & 1012 & 0 & 2 & 7 & 9 & 0.000 & 0.198 & 0.692 & 0.889 \\
\hline & $0.02 \%$ & 1214 & 0 & 1 & 12 & 13 & 0.000 & 0.082 & 0.988 & 1.071 \\
\hline & $0.03 \%$ & 1133 & 0 & 2 & 11 & 13 & 0.000 & 0.177 & 0.971 & 1.147 \\
\hline \multicolumn{2}{|c|}{ Mean } & - & - & - & - & - & - & - & - & 1.036 \\
\hline
\end{tabular}

Table 2: Frequency and spectrum of chlorophyll mutants in $\mathrm{M}_{2}$ generation of TBG 104

\begin{tabular}{|c|c|c|c|c|c|c|c|c|c|c|}
\hline \multirow{2}{*}{\multicolumn{2}{|c|}{ Treatments }} & \multirow{2}{*}{$\begin{array}{c}\text { Total number } \\
\text { of seedlings } \\
\text { examined }\end{array}$} & \multicolumn{3}{|c|}{ Types of chlorophyll mutants } & \multirow{2}{*}{\begin{tabular}{|c|}
$\begin{array}{c}\text { Total number of } \\
\text { Chlorophyll } \\
\text { mutants }\end{array}$ \\
\end{tabular}} & \multicolumn{3}{|c|}{$\begin{array}{c}\text { Relative percentage (Frequency) of } \\
\text { chlorophyll mutants }\end{array}$} & \multirow{2}{*}{$\begin{array}{c}\text { Chlorophyll } \\
\text { mutation } \\
\text { frequency (\%) }\end{array}$} \\
\hline & & & Albina & Xanth & Chlorina & & \begin{tabular}{|l|} 
Albina \\
\end{tabular} & Xantha & Chlorina & \\
\hline \multicolumn{2}{|c|}{ Control } & 2746 & & & & & & & & \\
\hline \multirow{5}{*}{$\begin{array}{c}\text { Gamma } \\
\text { rays }\end{array}$} & $200 \mathrm{~Gy}$ & 789 & 0 & 2 & 11 & 13 & 0.000 & 0.253 & 1.394 & 1.648 \\
\hline & $300 \mathrm{~Gy}$ & 1385 & 2 & 3 & 26 & 31 & 0.144 & 0.217 & 1.877 & 2.238 \\
\hline & $400 \mathrm{~Gy}$ & 903 & 0 & 0 & 22 & 22 & 0.000 & 0.000 & 2.436 & 2.436 \\
\hline & $500 \mathrm{~Gy}$ & 1375 & 2 & 7 & 27 & 36 & 0.145 & 0.509 & 1.964 & 2.618 \\
\hline & $600 \mathrm{~Gy}$ & 1455 & 3 & 1 & 38 & 42 & 0.206 & 0.069 & 2.612 & 2.887 \\
\hline \multicolumn{2}{|c|}{ Mean } & - & - & - & - & - & - & - & - & 2.365 \\
\hline \multirow{5}{*}{ EMS } & $0.2 \%$ & 1630 & 0 & 9 & 32 & 41 & 0.000 & 0.552 & 1.963 & 2.515 \\
\hline & $0.3 \%$ & 1410 & 2 & 2 & 36 & 40 & 0.142 & 0.142 & 2.553 & 2.837 \\
\hline & $0.4 \%$ & 1567 & 2 & 3 & 41 & 46 & 0.128 & 0.191 & 2.616 & 2.936 \\
\hline & $0.5 \%$ & 1519 & 12 & 7 & 36 & 55 & 0.790 & 0.461 & 2.370 & 3.621 \\
\hline & $0.6 \%$ & 1192 & 4 & 3 & 43 & 50 & 0.336 & 0.252 & 3.607 & 4.195 \\
\hline \multicolumn{2}{|c|}{ Mean } & - & - & - & - & - & - & - & - & 3.221 \\
\hline \multirow{3}{*}{$\mathrm{MH}$} & $0.01 \%$ & 599 & 0 & 1 & 20 & 21 & 0.000 & 0.167 & 3.339 & 3.506 \\
\hline & $0.02 \%$ & 585 & 0 & 0 & 30 & 30 & 0.000 & 0.000 & 5.128 & 5.128 \\
\hline & $0.03 \%$ & 353 & 0 & 1 & 24 & 25 & 0.000 & 0.283 & 6.799 & 7.082 \\
\hline \multicolumn{2}{|c|}{ Mean } & - & - & - & - & - & - & - & - & 5.238 \\
\hline
\end{tabular}

Table 3: Mutagenic effectiveness and efficiency based on chlorophyll mutants in LBG 752

\begin{tabular}{|c|c|c|c|c|c|c|c|c|c|}
\hline \multirow{2}{*}{\multicolumn{2}{|c|}{ Treatments }} & \multirow{2}{*}{$\begin{array}{l}\% \text { Survival } \\
\text { reduction at } \\
30^{\text {th }} \text { day }(\mathrm{L})\end{array}$} & \multirow{2}{*}{$\begin{array}{l}\% \text { Height } \\
\text { reduction at } \\
30^{\text {th }} \text { day ( I) }\end{array}$} & \multirow{2}{*}{\begin{tabular}{|c|}
$\%$ Pollen \\
fertility \\
reduction (S)
\end{tabular}} & \multirow{2}{*}{\begin{tabular}{|c|} 
Chlorophyll \\
mutation frequency \\
(\%) (Mc)
\end{tabular}} & \multirow{2}{*}{\begin{tabular}{|c|} 
Mutagenic \\
Effectiveness (\%) \\
Mc CxT (or) Gy
\end{tabular}} & \multicolumn{3}{|c|}{ Mutagenic efficiency (\%) } \\
\hline & & & & & & & $\frac{\text { Mc }}{\mathbf{L}}$ & $\frac{\mathbf{M c}}{\mathbf{I}}$ & $\frac{\mathrm{Mc}}{\mathrm{S}}$ \\
\hline \multicolumn{2}{|c|}{ Control } & - & - & - & - & - & - & - & - \\
\hline \multirow{5}{*}{ Gamma rays } & $200 \mathrm{~Gy}$ & 15.55 & 6.97 & 6.16 & 1.846 & 0.009 & 0.119 & 0.265 & 0.300 \\
\hline & $300 \mathrm{~Gy}$ & 39.83 & 8.33 & 25.75 & 2.198 & 0.007 & 0.055 & 0.264 & 0.085 \\
\hline & $400 \mathrm{~Gy}$ & 49.24 & 12.29 & 28.54 & 2.239 & 0.006 & 0.045 & 0.182 & 0.078 \\
\hline & $500 \mathrm{~Gy}$ & 59.53 & 14.92 & 37.60 & 2.305 & 0.005 & 0.039 & 0.154 & 0.061 \\
\hline & $600 \mathrm{~Gy}$ & 71.77 & 22.13 & 45.45 & 3.476 & 0.006 & 0.048 & 0.157 & 0.076 \\
\hline \multicolumn{2}{|c|}{ Mean } & - & - & - & - & 0.007 & 0.061 & 0.204 & 0.120 \\
\hline
\end{tabular}




\begin{tabular}{|c|c|c|c|c|c|c|c|c|c|}
\hline \multirow{5}{*}{ EMS } & $0.2 \%$ & 28.01 & 12.81 & 32.87 & 1.060 & 0.883 & 0.038 & 0.083 & 0.032 \\
\hline & $0.3 \%$ & 38.37 & 22.25 & 42.82 & 1.311 & 0.729 & 0.034 & 0.059 & 0.031 \\
\hline & $0.4 \%$ & 51.85 & 29.90 & 54.27 & 1.613 & 0.672 & 0.031 & 0.054 & 0.030 \\
\hline & $0.5 \%$ & 68.97 & 34.89 & 60.40 & 1.955 & 0.652 & 0.028 & 0.056 & 0.032 \\
\hline & $0.6 \%$ & 81.74 & 37.76 & 73.54 & 2.106 & 0.585 & 0.026 & 0.056 & 0.029 \\
\hline \multicolumn{2}{|c|}{ Mean } & - & - & - & & 0.704 & 0.031 & 0.062 & 0.031 \\
\hline \multirow{3}{*}{ MH } & $0.01 \%$ & 84.90 & 32.24 & 12.67 & 0.889 & 14.822 & 0.010 & 0.028 & 0.070 \\
\hline & $0.02 \%$ & 85.51 & 32.87 & 44.21 & 1.071 & 8.924 & 0.013 & 0.033 & 0.024 \\
\hline & $0.03 \%$ & 88.26 & 40.68 & 49.87 & 1.147 & 6.374 & 0.013 & 0.028 & 0.023 \\
\hline \multicolumn{2}{|c|}{ Mean } & - & - & - & - & 10.040 & 0.012 & 0.030 & 0.039 \\
\hline
\end{tabular}

L: Lethality; I: Injury; S: Sterility; Gy: Dose of gamma radiation; T: Duration of mutagenic treatment; C: Concentration of mutagen

Table 4: Mutagenic effectiveness and efficiency based on chlorophyll mutants in TBG 104

\begin{tabular}{|c|c|c|c|c|c|c|c|c|c|}
\hline \multirow{2}{*}{\multicolumn{2}{|c|}{ Treatments }} & \multirow{2}{*}{$\begin{array}{l}\text { \% Survival } \\
\text { reduction at } \\
30^{\text {th }} \text { day }(\mathrm{L})\end{array}$} & \multirow{2}{*}{$\begin{array}{l}\% \text { Height } \\
\text { reduction at } \\
30^{\text {th }} \text { day ( I) }\end{array}$} & \multirow{2}{*}{\begin{tabular}{|c|}
$\%$ Pollen \\
fertility \\
reduction (S)
\end{tabular}} & \multirow{2}{*}{\begin{tabular}{|c|} 
Chlorophyll \\
mutation frequency \\
(\%) (Mc) \\
\end{tabular}} & \multirow{2}{*}{\begin{tabular}{|c|} 
Mutagenic \\
Effectiveness (\%) $\mathbf{M c}$ \\
CxT (or) Gy \\
\end{tabular}} & \multicolumn{3}{|c|}{ Mutagenic efficiency (\%) } \\
\hline & & & & & & & $\frac{\text { Mc }}{\mathrm{L}}$ & $\frac{\mathbf{M c}}{\mathbf{I}}$ & $\frac{\text { Mc }}{\mathrm{S}}$ \\
\hline \multicolumn{2}{|c|}{ Control } & - & - & - & - & - & - & - & - \\
\hline \multirow{5}{*}{$\begin{array}{c}\text { Gamma } \\
\text { rays }\end{array}$} & $200 \mathrm{~Gy}$ & 9.88 & 9.00 & 3.32 & 1.648 & 0.008 & 0.167 & 0.183 & 0.496 \\
\hline & $300 \mathrm{~Gy}$ & 18.41 & 13.19 & 4.79 & 2.238 & 0.007 & 0.122 & 0.170 & 0.467 \\
\hline & $400 \mathrm{~Gy}$ & 43.73 & 14.86 & 16.27 & 2.436 & 0.006 & 0.056 & 0.164 & 0.150 \\
\hline & $500 \mathrm{~Gy}$ & 51.42 & 23.55 & 20.77 & 2.618 & 0.005 & 0.051 & 0.111 & 0.126 \\
\hline & $600 \mathrm{~Gy}$ & 58.78 & 35.05 & 20.97 & 2.887 & 0.005 & 0.049 & 0.082 & 0.138 \\
\hline \multicolumn{2}{|c|}{ Mean } & - & - & - & - & 0.006 & 0.089 & 0.142 & 0.275 \\
\hline \multirow{5}{*}{ EMS } & $0.2 \%$ & 5.94 & 3.79 & 2.70 & 2.515 & 2.096 & 0.423 & 0.664 & 0.932 \\
\hline & $0.3 \%$ & 23.77 & 18.78 & 6.67 & 2.837 & 1.576 & 0.119 & 0.151 & 0.425 \\
\hline & $0.4 \%$ & 41.39 & 31.03 & 12.96 & 2.936 & 1.223 & 0.071 & 0.095 & 0.227 \\
\hline & $0.5 \%$ & 52.31 & 35.34 & 47.81 & 3.621 & 1.207 & 0.069 & 0.102 & 0.076 \\
\hline & $0.6 \%$ & 64.89 & 53.60 & 51.01 & 4.195 & 1.165 & 0.065 & 0.078 & 0.082 \\
\hline \multicolumn{2}{|c|}{ Mean } & - & - & - & - & 1.453 & 0.149 & 0.218 & 0.348 \\
\hline \multirow{3}{*}{$\mathrm{MH}$} & $0.01 \%$ & 86.46 & 23.95 & 12.50 & 3.506 & 58.431 & 0.041 & 0.146 & 0.280 \\
\hline & $0.02 \%$ & 86.76 & 44.10 & 50.75 & 5.128 & 42.735 & 0.059 & 0.116 & 0.101 \\
\hline & $0.03 \%$ & 87.51 & 47.46 & 63.91 & 7.082 & 39.345 & 0.081 & 0.149 & 0.111 \\
\hline \multicolumn{2}{|c|}{ Mean } & - & - & - & - & 46.837 & 0.603 & 0.137 & 0.164 \\
\hline
\end{tabular}

L: Lethality; I: Injury; S: Sterility; Gy: Dose of gamma radiation; T: Duration of mutagenic treatment; C: Concentration of mutagen

\section{Conclusion}

The study on comparative effectiveness and efficiency of gamma rays, ethyl methane sulfonate and maleic hydrazide in induction of chlorophyll mutations on two black gram varieties viz., LBG 752 and TBG 104 revealed that the effectiveness and efficiency of chlorophyll mutations declined considerably with the increase in dose of the mutagens. It was also inferred from the present study that among the mutagens, MH treatments were more effective followed by EMS and gamma rays treatments in both the varieties. With respect to efficiency, the gamma rays were more efficient followed by EMS and MH treatments in both the varieties for inducing chlorophyll on the basis of injury, lethality and sterility except mutagenic efficiency based on lethality in TBG 104, where $\mathrm{MH}$ treatments showed higher value followed by gamma rays and EMS treatments. Hence, gamma rays could be considered as promising mutagen to get more frequency of desirable mutants than EMS and $\mathrm{MH}$ in blackgram as it was more efficient in both the blackgram varieties.

\section{References}

1. Bhosale UP, Hallale BV. Mutagenic effectiveness and efficiency of gamma rays and ethyl methane sulphonate in blackgram (Vigna mungo (L.) Hepper). Bionano Frontier. 2013; 6(2):271-273.

2. Bhosale UP, Hallale BV, Dubhashi SV. $\mathrm{M}_{1}$ generation studies in urdbean (Vigna mungo (L.) Hepper). Advances in Applied Science Research. 2013; 4(3):95-97.

3. Brock RD. Induced mutations in black gram. Radiation Botany. 1965; 5:451-464.

4. Deepalakshmi AJ, Kumar CRA. Efficiency and effectiveness of physical and chemical mutagens in urdbean (Vigna mungo (L.) Hepper). Madras Agricultural Journal. 2003; 90(7-9):485-489.

5. Dhasarathan $M$, Geetha S, Meenakshiganesan $N$, Sassikumar D. Studies on effectiveness and efficiency of gamma rays in blackgram (Vigna mungo (L.) Hepper). The Bioscan. 2017; 12(2):1155-1159.

6. Gaul H. Mutation in plant breeding. Radiation Botany. 1964; 4:155-232.

7. Gaul H, Frimel G, Gighner T, Ulonska E. Efficiency of mutagenesis. In: Induced mutation and plant improvement. Ed. IAEA/FAO, Londrina, 1972, 121-139.

8. Goyal S, Wani MR, Khan S. Frequency and spectrum of chlorophyll mutations induced by single and combination treatments of gamma rays and EMS in urdbean. Asian Journal of Biological Sciences. 2019; 12(2):156-163.

9. Gustafsson A. The mutation system of the chlorophyll apparatus. Lunds Univ. Arsskr. 1940; 36:1-40.

10. Khan IA, Hashim M. Mutagenic effectiveness and efficiency of gamma rays, EMS and hydrazine hydrate in Phaseolus aureus Roxb. Ind. J Bot. 1979; 2:107-110.

11. Konzak CF, Nilan RA, Wagner J, Foster RJ. Efficient chemical mutagenesis. Radiation Botany. 1965; 5:49-70.

12. Kousar M, Suresh BG. Mutagenic effectiveness and efficiency of gammarays, sodium azide and their synergistic effects in blackgram. World Journal of Agricultural Sciences. 2010; 6(2):234-237.

13. Ramchander L, Shunmugavalli N, Muthuswamy A, Rajesh S. Mutagenic effectiveness of chlorophyll and viable mutants in $\mathrm{M}_{2}$ generation of blackgram (Vigna mungo (L.) Hepper). International Journal of Applied Bioscience. 2018; 6(2):842-844. 
14. Reddi TVVS, Sunnetha J. Chlorophyll deficient mutations induced in rice by alkalyting agents and azide. Cytologia. 1992; 57:283-288.

15. Shadakshari YG, Chandrappa HM, Kulkarni RS, Shashidar AE. Induction of beneficial mutants in rice (Oryza sativa L.). Indian Journal of Genetics and Plant Breeding. 2001; 61:274-276.

16. Souframanien J, Reddy SK, Petwal VC, Dwivedi J. Comparative effectiveness and efficiency of electron beam and ${ }^{60} \mathrm{Co} \gamma$ - rays in induction of mutations in blackgram (Vigna mungo (L.) Hepper). Journal of Food Legumes. 2016; 29(1):1-6.

17. Surendar R, Vanniarajan C, Souframanien J. Effectiveness and efficiency of mutagens in gamma irradiated and EMS treated population of blackgram (Vigna mungo (L.) Hepper). International Journal of Tropical Agriculture. 2014; 32:79-84.

18. Tamilzharasi M, Kumaresan D, Souframanien J, Jayamani P. Study of chlorophyll deficit types through induced mutagenesis in blackgram (Vigna mungo L. Hepper). Electronic Journal of Plant Breeding. 2019; 10(4):1471-1476.

19. Usharani KS, Kumar CRA. Mutagenic efficiency and effectiveness of gamma rays and EMS and their combination in inducing chlorophyll mutations in $\mathrm{M}_{2}$ generation of Urdbean (Vigna mungo (L.) Hepper). Elecronic Journal of Plant Breeding. 2015; 6(1):210-217. 